\title{
Profiles of Endoglin and Vascular Endothelial Growth Factor Based on Staging and Histological Grading of Colorectal Cancer and Their Relationship with Bevacizumab Therapy
}

\section{Perfis da endoglina e do fator de crescimento endotelial vascular com base no estadiamento e na graduação histológica do câncer colorretal e sua relação com a terapia com bevacizumabe}

Rahmawati Minhajat ${ }^{1,2}$ Sahyuddin Saleh ${ }^{10}$ Tutik Harjianti ${ }^{10}$ Andi Fachruddin Benyamin ${ }^{10}$

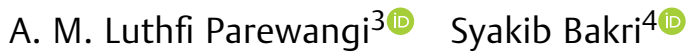

${ }^{1}$ Division of Hematology and Medical Oncology, Internal Medicine

Address for correspondence Rahmawati Minhajat, MD, PhD, Divisi Department, Faculty of Medicine at Hasanuddin University, Makassar, Indonesia

Hematologi Onkologi Medik Departemen Ilmu Penyakit Dalam, Fekultas Kedokteran Universitas Hasanuddin, Rumah Sakit UNHAS

${ }^{2}$ Department of Histology, Faculty of Medicine at Hasanuddin Gedung A Lantai 5, Jl. Perintis Kemerdekaan Km.11, Tamalanrea, University, Makassar, Indonesia

${ }^{3}$ Division of Gastroenterology and Hepatology, Internal Medicine Makassar-Indonesia (e-mail: rahmawati.minhajat@gmail.com).

Department, Faculty of Medicine at Hasanuddin University,

Makassar, Indonesia

${ }^{4}$ Division of Nephrology and Hypertension, Internal Medicine Department, Faculty of Medicine at Hasanuddin University,

Makassar, Indonesia

J Coloproctol 2021;41(2):156-162.
Abstract
Keywords
- angiogenesis
- bevacizumab
- colorectal adenocarcinoma
- CD105
- VEGF

Objective The present study evaluated the profile of endoglin (CD105) and vascular endothelial growth factor (VEGF) based on staging and histopathological grading of colorectal cancer as well as their relationship with bevacizumab therapy.

Methods A total of 88 cases of colorectal adenocarcinoma were included in the present study. The levels of VEGF and CD105 protein were evaluated with enzymelinked immunosorbent assay (ELISA).

Results There was a significant difference in the level of CD105 $(p=0.002)$ between metastases and non-metastases subjects, showing that CD105 was higher in metastases subjects $(4.59 \mathrm{ng} / \mathrm{ml})$. There was no significant difference in the level of VEGF based on the presence of metastasis $(p=0.625)$. There was a significant difference in the levels of CD105 $(p=0.038)$ and VEGF $(p=0.010)$ between the subjects who received received

August 11, 2020

accepted

September 7, 2020

published online

May 24, 2021
DOI https://doi.org/

$10.1055 / \mathrm{s}-0041-1724065$

ISSN 2237-9363. (c) 2021. Sociedade Brasileira de Coloproctologia. All rights reserved.

This is an open access article published by Thieme under the terms of the Creative Commons Attribution-NonDerivative-NonCommercial-License, permitting copying and reproduction so long as the original work is given appropriate credit. Contents may not be used for commercial purposes, or adapted, remixed, transformed or built upon. (https://creativecommons.org/ licenses/by-nc-nd/4.0/)

Thieme Revinter Publicações Ltda., Rua do Matoso 170, Rio de Janeiro, RJ, CEP 20270-135, Brazil 


\section{Resumo}

chemotherapy and those who did not. The CD105 level was higher in the subjects who received chemotherapy $(4.43 \mathrm{ng} / \mathrm{ml})$; conversely, the level of VEGF was lower in subjects who received chemotherapy $(543.65 \mathrm{pg} / \mathrm{ml})$. There was a statistically significant difference in the levels of CD105 $(p=0.003)$ and VEGF $(p=0.002)$ between subjects who received bevacizumab therapy and subjects who did not. The levels of CD105 were higher in subjects who received bevacizumab therapy $(5.11 \mathrm{ng} / \mathrm{ml})$; in contrast, the level of VEGF was higher in subjects who did not receive bevacizumab therapy $(645.92 \mathrm{pg} / \mathrm{ml})$. There was a significant positive correlation between CD105 and VEGF in subjects who did not receive bevacizumab $(p<0.01)$.

Conclusion The results of this study support a hypothesis of "escape mechanism" in the failure of anti-angiogenesis therapy (anti-VEGF).

Objetivo Este estudo avaliou o perfil da endoglina (CD105) e do fator de crescimento endotelial vascular (FCEV) com base no estadiamento e graduação histopatológica do câncer colorretal, assim como sua relação com a terapia com bevacizumabe.

Métodos No total, 88 casos de adenocarcinoma colorretal foram incluídos no presente estudo. Os níveis das proteínas FCEV e CD105 foram avaliados com ensaio imunoenzimático (ELISA, na sigla em inglês).

Resultados Houve uma diferença significativa no nível de CD105 $(p=0,002)$ entre indivíduos com metástases e sem metástases, que indicou que o nível de CD105 é mais alto em indivíduos com metástases $(4,59 \mathrm{ng} / \mathrm{ml})$. Não houve diferença significativa no nível de FCEV com base na presença de metástases $(p=0,625)$. Houve diferença significativa nos níveis de CD105 $(p=0,038)$ e de $\operatorname{FCEV}(p=0,010)$ entre os indivíduos que receberam quimioterapia e os que não receberam. Encontrou-se um nível de CD105 mais alto nos indivíduos que submetidos a quimioterapia $(4,43 \mathrm{ng} / \mathrm{ml}) ; \mathrm{Em}$ contrapartida, encontrou-se um nível de FCEV mais baixo em indivíduos que submetidos a quimioterapia $(543,65 \mathrm{pg} / \mathrm{ml})$. Houve uma diferença estatisticamente significativa nos níveis de CD105 $(p=0,003)$ e de FCEV $(p=0,002)$ entre os indivíduos submetidos e não submetidos à terapia com bevacizumabe. Os níveis de CD105 foram mais elevados em indivíduos submetidos à terapia com bevacizumab $(5,11 \mathrm{ng} / \mathrm{ml})$; em contraste, observou-se um nível de FCEV mais alto em indivíduos que não foram submetidos à terapia com bevacizumabe $(645,92 \mathrm{pg} / \mathrm{ml})$. Houve uma correlação positiva significativa entre CD105 e FCEV em indivíduos que não receberam bevacizumabe $(p<0,01)$.

Conclusão Os resultados deste estudo corroboram a hipótese de "mecanismo de escape" na falha da terapia anti-angiogênica (anti-FCEV).

\section{Introduction}

Colorectal adenocarcinoma is a malignancy caused by uncontrolled cell growth of the mucosal epithelium of the colorectum. The global burden of colorectal cancer is expected to increase by $60 \%$, or more than 2.2 million new cases and 1.1 million deaths, by $2030{ }^{1}$

The main cause of death of colorectal cancer is metastasis. Angiogenesis is a process of formation of new blood vessels from preexisting local blood vessels around the tumor through a sprouting mechanism. Angiogenesis allows tumor growth and metastasis because it ensures the availability of nutrients and oxygen for tumor cells and surrounding tissues It has been reported that tumor growth and metastasis is highly dependent on angiogenesis tumors and it is also reported that increased angiogenesis tumors are associated with poor prognosis. ${ }^{2}$

Because its involvement in solid tumors is strongly associated with tumor progression, angiogenesis is an important target in the therapy and prognosis of cancer. The guidelines of the European Society for Medical Oncology (ESMO) and the National Comprehensive Cancer Network (NCCN) for the management of advanced colorectal cancer suggest several chemotherapy regimens, such as FOLFOX, FOLFIRI, FOLFOXIRI, and CapeOX, which can be combined with anti-angiogenesis targeting therapy (anti-vascular endothelial growth factor [VEGF]/Bevacizumab) as the first-line therapy for colorectal cancer metastasis, except there is evidence of K-ras wild-type, 
so the targeting therapy is anti-epidermal growth factor receptor (anti-EGFR). ${ }^{3,4}$

The vascular endothelial growth factor is a key mediator of angiogenesis and binds to two VEGF receptors (VEGF receptor-1 and receptor-2), expressed on vascular endothelial cells. The VEGF is a key mediator of angiogenesis in cancer, in which there is increased regulation by increased expression of oncogenes, growth factors, and hypoxia. Anti-VEGF therapy has become an important choice for the management of malignancies. For colorectal cancer metastasis, bevacizumab (anti-VEGF) combined with chemotherapy regimens has superior efficacy compared with chemotherapy only. However, although progression-free survival and overall survival were longer than 2 months, compared with chemotherapy without bevacizumab, colorectal cancer progression persisted in the majority of patients, and many patients were reported to not respond to bevacizumab therapy either as a single agent or in combination with chemotherapy. It was reported that the benefits of bevacizumab therapy were relatively short, and the majority of patients became relapsed and progressive. Not all patients benefit clinically from the treatment, and the duration of the response in patients varies greatly. Resistance to anti-angiogenesis therapy with VEGF targets is thought to be due to the "escape mechanism" of tumor cells and surrounding tissue from its dependence on VEGF. ${ }^{5,6}$

Angiogenesis inhibition through non-VEGF pathways is expected to be a strategy that can enhance antitumor activity and resistance to anti-VEGF. One of the most widely studied non-VEGF angiogenesis pathways currently targeted is endoglin (CD105) inhibition., ${ }^{7,8}$

Endoglin is a cell adhesion molecule. It is the accessory receptor of transforming growth factor- $\beta$ (TGF- $\beta$ ), which is a pleiotropic cytokine that modulates angiogenesis through regulation of cell function, including proliferation, differentiation, and migration, and its expression increases in proliferating active endothelial cells. Endoglin proteins are expressed on endothelial surfaces that actively proliferate and modulate angiogenesis through TGF- $\beta$ signals, activin-like kinase-1 (ALK-1), and Smad proteins. ${ }^{7,8}$

Increased CD105 expression correlates inversely with the clinical conditions of various malignancies, including colorectal cancer. It was reported that elevated serum endoglin was associated with increased metastasis in patients with solid tumors. ${ }^{9,10}$ Based on the results of many studies, CD105 can be a target, and anti-CD105 antibody can be a candidate for anti-angiogenesis therapy of colorectal cancer and should be considered when trying to overcome the existence of tumor resistance to anti-angiogenesis therapy ${ }^{9}$. In recent years, a multicenter study has begun to combine anti-CD105 (TCRC105) with bevacizumab (anti-VEGF). However, in our review of the literature, we have not found any study that evaluates and compares the levels of VEGF and CD105 proteins in non-metastasis and metastasis colorectal cancer patients and their correlation with grading histology. 7,10,11 In the present study, we evaluated the profile of proteins CD105 and VEGF based on staging and histopathological grading of colorectal cancer and evaluated their relationship with bevacizumab therapy.

\section{Materials and Methods}

The present article consists of an observational study with a cross-sectional approach. The study was conducted at the Hasanuddin University Hospital Makassar, Indonesia, and its network hospital, from January to December 2017. The samples were obtained from colorectal cancer patients who have performed the pathological examination of the surgical resection and diagnosed as colorectal adenocarcinoma. The levels of VEGF and CD105 were evaluated with enzyme-linked immunosorbent assay (ELISA).

The measurement of VEGF and CD105 protein serum patients was performed with ELISA. As much as $5 \mathrm{ml}$ of venous blood was taken from each subject and left in the tube at room temperature. Then, the serum was separated by centrifugation and stored in a cooler at a temperature of $-80^{\circ}$ Celsius until the analysis was performed. The analysis procedure was performed according to the instructions in the kit (Bio-Rad Laboratories, Hercules, CA, USA). Finally, $0.1 \mathrm{ml}$ of $1 \mathrm{~N} \mathrm{H} 2 \mathrm{SO} 4$ solution was added to each sample. The optical density (absorbance) of each sample was interpreted using an automatic ELISA reader (Anthos-Labtec Instruments, Salzburg, Austria) at a wavelength of $450 \mathrm{~nm}$, with the reference wavelength of $690 \mathrm{~nm}$. The standard curve for the VEGF and CD105 level is determined by taking the standard logarithm value as Y-axis and absorbance value as X-axis. Each blood specimen was measured for VEGF and CD105 concentration, and the level in the specimen was determined from the standard curve plot.

The Mann-Whitney and Kruskal-Wallis tests were used to assess statistically the serum levels of CD105 and VEGF according to metastasis, therapy with conventional chemotherapy, and therapy with bevacizumab. The Spearman correlation test was used to assess the correlation between CD105 and VEGF. The results were considered statistically significant if $p$-value $<0.05$.

The present study was run and finished with the approval Recommendation of the Ethics Commission of Human Health Research from the Medical Faculty Hasanuddin University.

\section{Results}

A total of 88 cases of colorectal adenocarcinoma were included in this study. Based on the subject characteristics, this study found $54.5 \%$ male, the highest age range was 60 to 77 years (39.8\%) followed by 20 to 49 years (36.4\%). The most tumor location was in the rectum (31.8\%) and most of the subjects were in stage IV (48.9\%), and $61.4 \%$ had metastasized to the regional lymph nodes or distant metastases. The most often histopathological grading which found was moderately differentiated adenocarcinoma (44.3\%). Based on the therapy that had been obtained, subjects who had received chemotherapy was $58 \%$, of which $35.3 \%$ had already received combination therapy with bevacizumab (-Table $\mathbf{1}$ ). 
Table 1 Patients' characteristics $(n=88)$

\begin{tabular}{|c|c|c|c|}
\hline Variable & Category & $\mathrm{n}$ & $\%$ \\
\hline \multirow[t]{2}{*}{ Gender } & Male & 48 & 54.5 \\
\hline & Female & 40 & 45.5 \\
\hline \multirow[t]{3}{*}{ Age } & $20-49$ years old & 32 & 36.4 \\
\hline & 50-59 years old & 21 & 23.9 \\
\hline & $60-77$ years old & 35 & 39.8 \\
\hline \multirow[t]{5}{*}{ Tumor location } & Ascending colon & 15 & 17.0 \\
\hline & Transversal colon & 3 & 3.4 \\
\hline & Descending colon & 16 & 18.2 \\
\hline & Rectosigmoid & 26 & 29.5 \\
\hline & Rectum & 28 & 31.8 \\
\hline \multirow[t]{2}{*}{ Metastasis } & Yes & 54 & 61.4 \\
\hline & No & 34 & 38.6 \\
\hline \multirow[t]{4}{*}{ Staging } & 1 & 19 & 21.6 \\
\hline & II & 15 & 17.1 \\
\hline & III & 11 & 12.5 \\
\hline & IV & 43 & 48.9 \\
\hline \multirow{4}{*}{$\begin{array}{l}\text { Grading } \\
\text { histology }\end{array}$} & Well-differentiated & 29 & 33.0 \\
\hline & Moderate & 39 & 44.3 \\
\hline & Poor & 16 & 18.2 \\
\hline & Mucinous & 4 & 4.5 \\
\hline \multirow[t]{2}{*}{ Chemotherapy } & Yes & 51 & 58 \\
\hline & No & 37 & 42 \\
\hline \multirow{2}{*}{$\begin{array}{l}\text { Chemotherapy }+ \\
\text { Bevacizumab }\end{array}$} & Yes & 18 & 35.3 \\
\hline & No & 33 & 64.7 \\
\hline
\end{tabular}

Abbreviation: $\mathrm{n}$, number.

Using the ELISA, we found the mean of CD105 and VEGF protein serum levels were $4.25 \mathrm{ng} / \mathrm{ml}$ and $610.21 \mathrm{ng} / \mathrm{l}$ respectively (-Table $\mathbf{2}$ ).

There was a significant positive correlation $(p<0.05)$ between CD105 and VEGF levels in subjects with colorectal adenocarcinoma, where the higher level of protein CD105 the higher level of VEGF (-Fig. 1).

Analysis of CD105 and VEGF protein serum levels based on the presence of metastases found a significant difference in mean of CD105 levels ( $p=0.002)$. In contrast, there was no significant difference in mean of VEGF levels based on the presence of metastases ( $p=0.625)$, although it was seen that

Table 2 Serum level of proteins CD105 and VEGF $(n=88)$

\begin{tabular}{|l|l|l|l|l|}
\hline Variable & Minimum & Maximum & Mean & SD \\
\hline $\begin{array}{l}\text { CD105 } \\
(\mathrm{ng} / \mathrm{ml})\end{array}$ & 1.69 & 7.55 & 4.25 & 1.37 \\
\hline $\begin{array}{l}\text { VEGF } \\
(\mathrm{pg} / \mathrm{ml})\end{array}$ & 20.21 & $2,758.89$ & 610.21 & 583.20 \\
\hline
\end{tabular}

Abbreviations: CD105, endoglin; VEGF, vascular endothelial growth factor; SD, standard deviation.
VEGF levels tended to be higher in colorectal cancer metastases ( - Table 3 ).

This study found differed significantly $(p=0.038)$ between subjects who received chemotherapy and those who did not receive chemotherapy, where CD105 levels were significantly higher in subjects who received chemotherapy $(4.43 \mathrm{ng} / \mathrm{ml})$. Similarly, the VEGF levels were significant differences in the mean of VEGF levels between subjects who received chemotherapy and those who did not receive chemotherapy $(p=0.010)$, but different from CD105 levels, VEGF levels were lower in subjects who received chemotherapy (543.65 $\mathrm{pg} / \mathrm{ml}$ ) (-Table 4).

Analysis of CD105 and VEGF protein serum levels based on bevacizumab additional therapy to subjects receiving chemotherapy found significant differences $(p=0.003)$ on mean of CD105 levels among subjects receiving bevacizumab therapy and without bevacizumab, where CD105 levels were higher in subjects who received bevacizumab $(5.11 \mathrm{ng} / \mathrm{ml})$. In contrast to CD105, although there were also significant differences $(p=0.002)$ between subjects who received bevacizumab therapy and without bevacizumab, VEGF levels were significantly higher in subjects who did not receive bevacizumab (645.92 pg/ml) (-Table 5).

Analysis of CD105 and VEGF protein levels based on histopathological grading found a significant difference of CD105 levels $(p<0.009)$, where CD105 levels were significantly higher in poorly differentiation $(5.17 \mathrm{ng} / \mathrm{ml})$. Similarly, the VEGF levels have significant differences $(p<0.025)$, where VEGF levels were significantly higher in poorly differentiation (909.47 pg/ml) (-Table 6).

We evaluated the correlation between CD105 and VEGF protein serum levels in subjects who received chemotherapy with bevacizumab and subjects without bevacizumab (-Fig. 2a). There was a significant positive correlation between CD105 and VEGF levels in subjects who did not receive bevacizumab $(p<0.01)$ ( - Fig. 2 ). Conversely, no significant correlation was found between CD105 and VEGF levels in subjects who received bevacizumab $(\mathrm{p}>0.05)$ (-Fig. 2b).

\section{Discussion}

The mechanisms of growth and metastasis of colorectal adenocarcinoma is facilitated by angiogenesis. ${ }^{12}$ The present study found that the serum level of VEGF in colorectal cancer patients was $610.21 \mathrm{pg} / \mathrm{ml}$, not much different from the one found in the study by Nakamura (2013), who reported a VEGF serum level of $601.8 \mathrm{pg} / \mathrm{ml}^{13}{ }^{13} \mathrm{Li}$ et al., (2003) reported that the plasma level of CD105 from 76 colorectal cancer patients was $3.46 \pm 1.30 \mathrm{ng} / \mathrm{ml}$. Our study found the CD105 level was $4.25 \pm 1.37 .^{14}$ The present study found a significant positive correlation $(p<0.05)$ between CD105 and VEGF levels.

It was reported that increased serum CD105 levels are associated with increased metastasis in patients with solid tumors, including colorectal cancer. In the present study, the serum level of CD105 protein were significantly higher in colorectal adenocarcinoma patients with metastases than in 


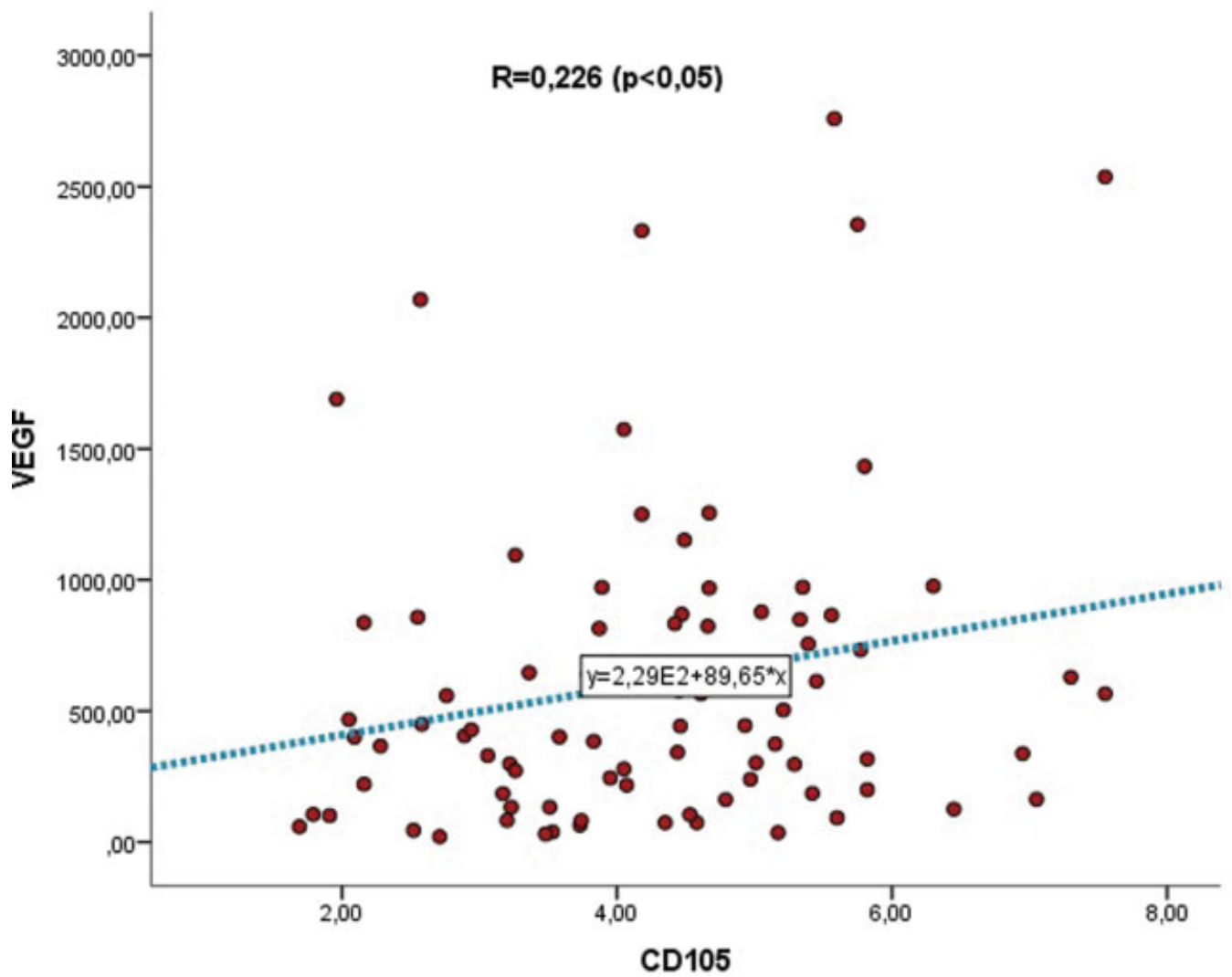

Fig. 1 Correlation between CD105 and VEGF protein serum level in patients with colorectal adenocarcinoma.

those without metastases $(p=0.002)$. Takahashi (2001) also reported a significant increase in serum CD105 protein levels associated with metastasis in patients with solid tumors, including colorectal cancer, wherein a significant difference was found between the levels of serum CD105 in metastatic colorectal cancer patients with and without metastasis $(p=0.012) .{ }^{9} \mathrm{Li}(2003)$ reported that the level of CD105 was positively associated with colorectal cancer based on the Dukes' classification, staging, and patient's survival. ${ }^{14}$ The results of our previous study also proved that CD105 protein was specifically expressed in vascular endothelial cells in colorectal cancer xenograft models, and anti-CD105 antibodies have been shown to inhibit tumor growth and hematogenous metastasis through vascular system inhibition. $^{15}$

Table 3 Analysis of the serum level of proteins CD105 and VEGF based on metastasis

\begin{tabular}{|l|l|l|l|l|l|}
\hline Variable & Metastasis & $\mathbf{n}$ & Mean & SD & p-value \\
\hline \multirow{2}{*}{$\begin{array}{l}\text { CD105 } \\
(\mathrm{ng} / \mathrm{ml})\end{array}$} & Yes & 54 & 4.59 & 1.35 & \multirow{2}{*}{$0.002^{*}$} \\
\cline { 2 - 5 } & No & 34 & 3.71 & 1.24 & \\
\hline \multirow{2}{*}{$\begin{array}{l}\text { VEGF } \\
(\mathrm{pg} / \mathrm{ml})\end{array}$} & Yes & 54 & 650.27 & 635.58 & \multirow{2}{*}{$0.625^{*}$} \\
\cline { 2 - 5 } & No & 34 & 546.58 & 491.01 & \\
\hline
\end{tabular}

Abbreviations: CD105, endoglin; VEGF, vascular endothelial growth factor; n, number; SD, standard deviation.

*Mann-Whitney test.
However, in contrast to CD105, it appears that the serum level of VEGF is higher in colorectal cancer with metastases than those without metastases. In the present study, there was no significant difference in the serum level of VEGF based on the presence of metastases $(p=0.625)$. This result might be influenced by the fact that $35.3 \%$ of the subjects in this study had received anti-angiogenesis (anti-VEGF/bevacizumab) therapy. Another factor that might have influenced this result was VEGF and its receptors, which proved to play an important role to promote angiogenesis, not only in pathological conditions, but also in physiological angiogenesis.

Based on histopathological grading, the present study found a statistically significant difference in the levels of CD105( $p<0.009)$, in which CD105 levels were significantly

Table 4 Analysis of the serum level of proteins CD105 and VEGF based on chemotherapy $(N=88)$

\begin{tabular}{|l|l|l|l|l|l|}
\hline Variable & Chemotherapy & $\mathbf{n}$ & Mean & SD & p-value \\
\hline $\begin{array}{l}\text { CD105 } \\
(\mathrm{ng} / \mathrm{ml})\end{array}$ & Yes & 51 & 4.43 & 1.42 & $0.038^{*}$ \\
\cline { 2 - 5 } & No & 37 & 4.00 & 1.25 & \\
\hline \multirow{2}{*}{$\begin{array}{l}\text { VEGF } \\
(\mathrm{pg} / \mathrm{ml})\end{array}$} & Yes & 51 & 543.65 & 400.58 & $0.010^{*}$ \\
\cline { 2 - 5 } & No & 37 & 701.94 & 441.17 & \\
\hline
\end{tabular}

Abbreviations: CD105, endoglin; VEGF, vascular endothelial growth factor; n, number; SD, standard deviation.

${ }^{*}$ Kruskal-Wallis test. 
Profiles of Endoglin and Vascular Endothelial Growth Factor Based on Staging and Histological Minhajat et al. 161

Table 5 Analysis of the serum level of proteins CD105 dan VEGF based on bevacizumab additional therapy

\begin{tabular}{|l|l|l|l|l|l|}
\hline Variable & Bevacizumab & $\mathbf{n}$ & Mean & SD & p-value \\
\hline \multirow{2}{*}{$\begin{array}{l}\text { CD105 } \\
(\mathrm{ng} / \mathrm{ml})\end{array}$} & Yes & 18 & 5.11 & 1.30 & \multirow{2}{*}{$0.003^{*}$} \\
\cline { 2 - 5 } & No & 33 & 4.06 & 1.38 & \\
\hline \multirow{2}{*}{$\begin{array}{l}\text { VEGF } \\
\text { (pg/ml) }\end{array}$} & Yes & 18 & 356.16 & 589.19 & \multirow{2}{*}{$0.002^{*}$} \\
\cline { 2 - 5 } & No & 33 & 645.92 & 565.91 & \\
\hline
\end{tabular}

Abbreviations: CD105, endoglin; VEGF, vascular endothelial growth factor; n, number; SD, standard deviation.

${ }^{*}$ Mann-Whitney test.

higher in poorly differentiated tissues $(5.17 \mathrm{ng} / \mathrm{ml})$. Similarly, the VEGF levels have significant differences $(p<0.025)$, in which VEGF levels were significantly higher in poor differentiated tissues (909.47 pg/ml). Our previous study, using immunohistochemical methods, had proven that the highest CD105 protein expression was found in poorly differentiated colorectal cancer tissue. ${ }^{16}$ In the present study, there were only four subjects with mucinous histopathology, which were included in the poorly differentiated tissue group.

There was a statistically significant difference in the levels of both CD105 $(p=0.038)$ and VEGF $(p=0.010)$ between subjects receiving chemotherapy and those who did not, but differently from CD105, which was higher in subjects who received chemotherapy $(4.43 \mathrm{ng} / \mathrm{ml})$, VEGF levels were found to be lower in subjects receiving chemotherapy (543.65 pg/ml).

Azzariti (2016) reported that there was a significant decrease in the level of $\operatorname{VEGF}(p<0.05)$ in a study comparing the levels of VEGF after administration of two and five cycles of oxaliplatin-based chemotherapy without bevacizumab. ${ }^{17}$

Aoyagi (2010) reported the decrease levels of VEGF protein in 46 patients with advanced stage colorectal cancer who received FOLFOX regimen with bevacizumab combination; the mean level was $156.4 \pm 71.5 \mathrm{pg} / \mathrm{ml}^{18}$ In the present study, analysis of the serum levels of CD105 and VEGF based on bevacizumab additional therapy to subjects receiving chemotherapy found significant differences $(p=0.003)$ in the level of

Table 6 Analysis of the serum level of proteins CD105 and VEGF based on histological grading

\begin{tabular}{|c|c|c|c|c|c|}
\hline Variable & Histological grading & $\mathbf{n}$ & Mean & SD & $p$-value \\
\hline \multirow[t]{4}{*}{ CD105 (ng/ml) } & Well-differentiated Differentiation & 29 & 3.95 & 1.40 & \multirow[t]{4}{*}{$0.009^{*}$} \\
\hline & Moderate Differentiation & 39 & 4.16 & 1.37 & \\
\hline & Poor Differentiation & 16 & 5.17 & 0.92 & \\
\hline & Mucinous & 4 & 3.59 & 1.47 & \\
\hline \multirow[t]{4}{*}{ VEGF (pg/ml) } & Well-differentiated Differentiation & 29 & 511.77 & 513.84 & \multirow[t]{4}{*}{$0.025^{*}$} \\
\hline & Moderate Differentiation & 39 & 565.95 & 636.46 & \\
\hline & Poor Differentiation & 16 & 909.47 & 567.85 & \\
\hline & Mucinous & 4 & 558.31 & 235.74 & \\
\hline
\end{tabular}

Abbreviations: CD105, endoglin; VEGF, vascular endothelial growth factor; n, number; SD, standard deviation.

*Kruskal-Wallis test.
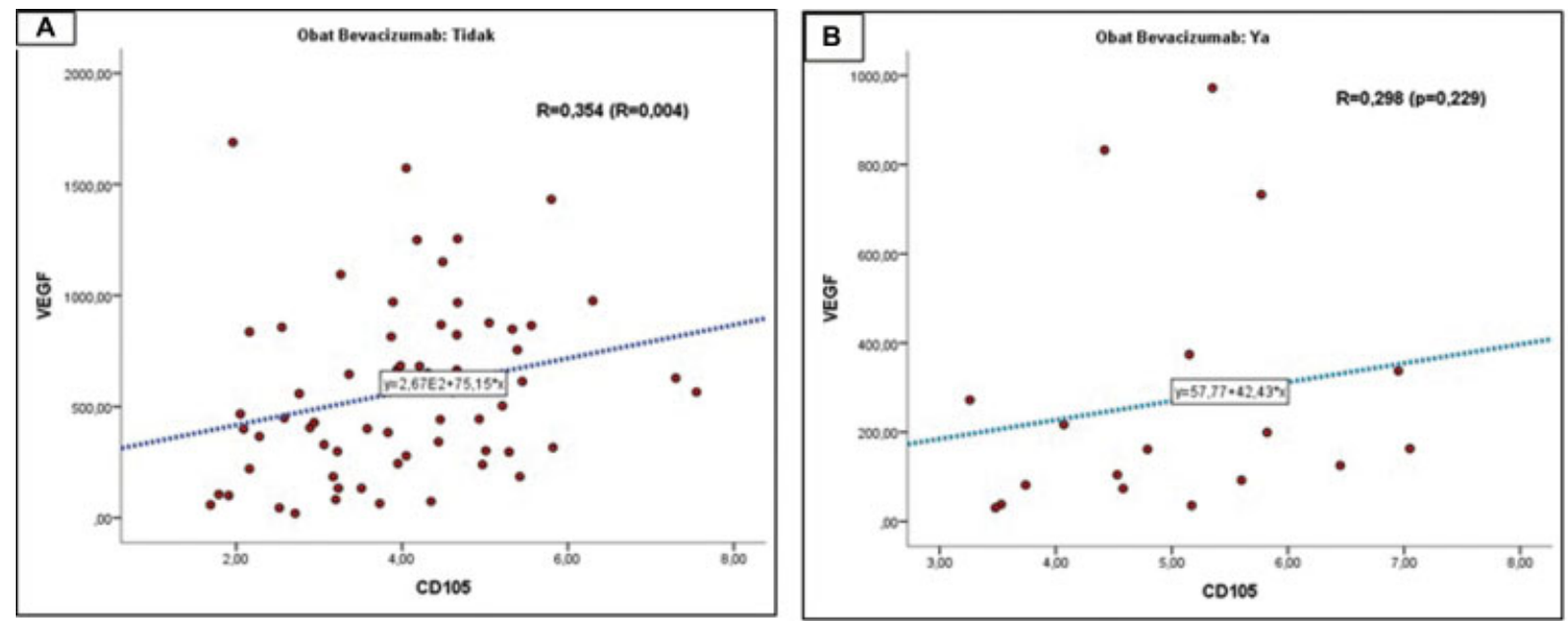

Fig. 2 The correlation between CD105 and VEGF protein serum levels in patients (A) without therapy of bevacizumab and (B) the subjects receiving bevacizumab. 
CD105 among subjects who received bevacizumab and those who didn't, in which CD105 level was higher in subjects receiving bevacizumab $(5.11 \mathrm{ng} / \mathrm{ml})$. In contrast to $\mathrm{CD} 105$, although there were also significant differences $(p=0.002)$ between subjects received bevacizumab and those who did not, VEGF levels were significantly higher in subjects who did not receive bevacizumab $(645.92 \mathrm{pg} / \mathrm{ml}$ ) (-Table 5). The reverse pattern of CD105 and VEGF protein levels, in which CD105 protein levels are higher and VEGF protein levels are lower in subjects who have received bevacizumab can support a theory of an "escape mechanism" in the failure of anti-angiogenesis therapy (anti-VEGF). ${ }^{5}$

Furthermore, we found a significant positive correlation between VEGF and CD105 levels in subjects who did not receive bevacizumab $(p<0.01)$, in which the higher the level of VEGF, the higher level of CD105. Conversely, there was no significant correlation between CD105 and VEGF protein levels in subjects receiving bevacizumab $(p>0.05)$.

\section{Conclusion}

There is a positive correlation between increased CD105 and VEGF levels and colorectal cancer, but in subjects receiving bevacizumab, serum VEGF protein levels are lower, whereas serum CD105 protein is higher. The results of the present study support the hypothesis of "escape mechanism" in the failure of anti-angiogenesis therapy (anti-VEGF).

\section{Funding}

The present study received no specific grant from any funding agency in the public, commercial, or not-forprofit sectors.

\section{Conflict of Interests}

The authors have no conflict of interests to declare.

\section{Acknowledgments}

The authors thank the laboratory staff for their assistance. The present study would not have been possible without the enthusiastic cooperation of the participants.

\section{References}

1 Arnold M, Sierra MS, Laversanne M, Soerjomataram I, Jemal A, Bray F. Global patterns and trends in colorectal cancer incidence and mortality. Gut 2017;66(04):683-691

2 Arjaans M, Schröder CP, Oosting SF, Dafni U, Kleibeuker JE, de Vries EG. VEGF pathway targeting agents, vessel normalization and tumor drug uptake: from bench to bedside. Oncotarget 2016;7 (16):21247-21258

3 Van Cutsem E, Cervantes A, Adam R, et al. ESMO consensus guidelines for the management of patients with metastatic colorectal cancer. Ann Oncol 2016;27(08):1386-1422

4 Engstrom PF, Arnoletti JP, Benson AB III, et al; National Comprehensive Cancer Network. NCCN Clinical practice guidelines in oncology: colon cancer. J Natl Compr Canc Netw 2009;7(08):778-831

5 Gacche RN. Compensatory angiogenesis and tumor refractoriness. Oncogenesis 2015;4(06): 153

6 Rapisarda A, Melillo G. Role of the VEGF/VEGFR axis in cancer biology and therapy. Adv Cancer Res 2012;114:237-267

7 Rosen LS, Gordon MS, Robert F, Matei DE. Endoglin for targeted cancer treatment. Curr Oncol Rep 2014;16(02):365

8 Fonsatti E, Altomonte M, Arslan P, Maio M. Endoglin (CD105): a target for anti-angiogenetic cancer therapy. Curr Drug Targets 2003;4(04):291-296

9 Takahashi N, Kawanishi-Tabata R, Haba A, et al. Association of serum endoglin with metastasis in patients with colorectal, breast, and other solid tumors, and suppressive effect of chemotherapy on the serum endoglin. Clin Cancer Res 2001;7(03):524-532

10 Paauwe M, Heijkants RC, Oudt $\mathrm{CH}$, et al. Endoglin targeting inhibits tumor angiogenesis and metastatic spread in breast cancer. Oncogene 2016;35(31):4069-4079

11 Seon BK, Haba A, Matsuno F, et al. Endoglin-targeted cancer therapy. Curr Drug Deliv 2011;8(01):135-143

12 Folkman J. What is the evidence that tumors are angiogenesis dependent? J Natl Cancer Inst 1990;82(01):4-6

13 Nakamura I, Shibata M, Gonda K, et al. Serum levels of vascular endothelial growth factor are increased and correlate with malnutrition, immunosuppression involving MDSCs and systemic inflammation in patients with cancer of the digestive system. Oncol Lett 2013;5(05):1682-1686

14 Li C, Gardy R, Seon BK, et al. Both high intratumoral microvessel density determined using CD105 antibody and elevated plasma levels of $\mathrm{CD} 105$ in colorectal cancer patients correlate with poor prognosis. Br J Cancer 2003;88(09):1424-1431

15 Minhajat R, Mori D, Tokunaga O, et al. Anti-CD105 Inhibits Primary Cancer Growth and Secondary Hematogenous Metastasis in a Xenograft Model. Vasc Dis Prev 2009;6:91-96

16 Minhajat R, Mori D, Yamasaki F, Sugita Y, Satoh T, Tokunaga O. Endoglin (CD105) expression in angiogenesis of colon cancer: analysis using tissue microarrays and comparison with other endothelial markers. Virchows Arch 2006;448 (02):127-134

17 Azzariti A, Porcelli L, Brunetti O, et al. Total and not bevacizumab-bound vascular endothelial growth factor as potential predictive factors to bevacizumab-based chemotherapy in colorectal cancer. World J Gastroenterol 2016;22(27):62876295

18 Aoyagi Y, Iinuma H, Horiuchi A, Shimada R, Watanabe T. Association of plasma VEGF-A, soluble VEGFR-1 and VEGFR-2 levels and clinical response and survival in advanced colorectal cancer patients receiving bevacizumab with modified FOLFOX6. Oncol Lett 2010;1(02):253-259 